\title{
Housing conditions, respiratory illness, and lung function in children in South Wales
}

\author{
J. W. G. YARNELL AND A. S. ST LEGER \\ From the MRC Epidemiology Unit, Cardiff
}

SUMMARY The hypothesis was tested that respiratory illness in children occurs more commonly in old housing than in housing built to modern standards. Three areas of housing were chosen in a South Wales valley: a recently constructed council estate with district central heating; a modern council estate heated with open coal fires; and an area of much older, traditional valley housing. Mothers reported the greatest proportion of children free of colds and sore throats during the previous 12 months in the area of traditional valley housing; mothers of children in the centrally heated estate reported the least proportion of children free of colds. Children's lung function was best in the area of traditional valley housing and worst in the centrally heated council estate. Data on demographic indices and respiratory morbidity suggest that the inhabitants of the two council estates have comparable characteristics. Another hypothesis which may explain the findings is proposed.

Respiratory illness is common in childhood but its long-term effects are not easy to prove and only recently has epidemiological research shown a relationship to exist between the occurrence of pneumonia or bronchitis in early childhood and impaired lung function in later life (Bland et al., 1974), and also between respiratory illnesses in childhood and increased respiratory disease in adult life (Colley et al., 1973). Among other environmental factors, housing conditions have been suggested as contributory to the development of respiratory disease in children (Holland et al., 1969).

The present study arose from an invitation from the local authority to study the health of children living on a recently constructed council estate with district central heating (Area A). The opportunity was therefore taken to compare the prevalence of respiratory disease in children living on this estate with that of children living in two other nearby areas of housing: a comparable, modern council estate heated by open coal fires (Area B); and a third area of traditional valley housing built in the late nineteenth century, also predominantly heated by open coal fires (Area C). South Wales appeared to be a pertinent site for the study since, in a study conducted in several areas of England and Wales (Colley and Reid, 1970), South Wales emerged with an unexplained excess prevalence of bronchitis in both adults and children.
The working hypothesis of the study was that respiratory illness would be less common among children living on the council estate with central heating (Area Á), who, it was believed, had the benefit of an optimal domestic environment, than among children living in the other areas of housing (Areas B and C).

\section{Methods}

All study areas are sited within areas where coalmining was once the major source of employment, but most of the working population is now predominantly employed in other manual occupations. Area A, the modern council estate with district central heating, is situated in an elevated exposed position at 1300 feet $(396 \mathrm{~m})$ between two valleys; the first tenants came to the estate in 1968. Area B, a smaller council estate situated 15 miles south, at 1000 feet $(305 \mathrm{~m})$, was selected for comparison; the estate was first occupied in 1964. The third area, Area C, traditional housing, is close to the first estate; the dwellings situated on both sides of the valley are on average 800 feet $(244 \mathrm{~m})$ above sea level; they are predominantly privately owned or rented from the National Coal Board.

A private census was undertaken in each area to select all houses containing children under the age of 11 years resident at the same address during the previous 12 months; the sample for the main study 
consisted of a random sample of these houses in each area.

Parents of children in the selected houses were contacted by letter; mothers were interviewed at home by the first author and by other fieldworkers during the spring and summer months of 1975. Lung function tests were performed at school on children older than seven years of age during the summer term by use of a bellows spirometer, the Vitalograph. It was not possible to measure the lung function of younger children with this instrument because of its internal resistance. Each child was allowed two attempts and the results were calculated from the maximum of three further readings. All measurements were made by a single experienced operator. The height and weight of each child was also measured.

Lung function indices calculated included: the forced mid-expiratory flow (FMF); the forced expiratory volume in three-quarters of a second $\left(F V_{0.75}\right)$; the forced vital capacity (FVC). Their significance, sensitivity, and reproducibility have been fully discussed elsewhere (Cotes, 1975). Meteorological data were obtained and if necessary gas volumes were corrected for ambient temperature and pressure.

\section{Results}

The overall response rates are summarised in Table 1. Absence from school accounted for the lower response rates in the sample of children eligible for lung function tests.

Table 1 Composition of study sample

\begin{tabular}{ll}
\hline Study sample & No. \\
\hline Children & \\
Under 11 years of age & 767 \\
Whose mothers were not interviewed & 4 \\
Respondents (response) & $763(99 \%)$ \\
Children & 221 \\
Eligible for lung function tests & 7 \\
Unavailable for tests & $214(97 \%)$ \\
Tested (response) & \\
\hline
\end{tabular}

It was predicted that the inhabitants of the two council estates, Areas A and B, would share more characteristics than they would with the inhabitants of the traditional valley housing, Area C. Table 2 demonstrates that this was the case. Data which did not suggest differences between the three areas have been omitted from the table. For example the age and sex distributions of children aged 11 years or less were comparable in all areas, apart from a marked excess of boys in the area of traditional housing (122 boys against 91 girls). Seventy-five per cent of all families had been resident at the
Table 2 Demographic, medical, and social characteristics 0 of families and children in study areas

\begin{tabular}{|c|c|c|c|}
\hline Characteristics & Area & $\underset{B}{\text { Area }}$ & Area \\
\hline $\begin{array}{l}\text { Number } \\
\text { Of families } \\
\text { Of children }\end{array}$ & $\begin{array}{l}148 \\
298\end{array}$ & $\begin{array}{l}125 \\
252\end{array}$ & $\begin{array}{l}135 \\
213\end{array}$ \\
\hline Median period residence (years) & $4 \cdot 0$ & $6 \cdot 5$ & \\
\hline $\begin{array}{l}\text { Of children aged } 11 \text { years or less per family } \\
\text { Of children per family } \\
\text { Of children per bedroom }\end{array}$ & $\begin{array}{l}2 \cdot 0 \\
2 \cdot 7 \\
1 \cdot 3\end{array}$ & $\begin{array}{l}2 \cdot 0 \\
3 \cdot 1 \\
1 \cdot 5\end{array}$ & $1 \cdot$ \\
\hline $\begin{array}{l}\text { ercentages of } \\
\text { Head of household unemployed } \\
\text { Single parent families } \\
\text { Head of household non-manual occupation } \\
\text { Mothers non-smokers } \\
\text { Mothers smoking } 20 \text { cigarettes or more daily } \\
\text { Households in which no cigarettes smoked } \\
\text { Households in which } 20 \text { cigarettes or more }\end{array}$ & $\begin{array}{l}20 \\
11 \\
11 \\
37 \\
33 \\
13\end{array}$ & $\begin{array}{r}24 \\
8 \\
1 \\
34 \\
33 \\
13\end{array}$ & $\begin{array}{r}8 \\
2 \\
6 \\
55 \\
16 \\
21\end{array}$ \\
\hline smoked daily (a) & 41 & 37 & 34 \\
\hline $\begin{array}{l}\text { Families with two or more children aged } 11 \\
\text { years or less with younger sibling(s) } \\
\text { aged } 4-6 \text { years }\end{array}$ & 39 & 35 & 32 \\
\hline Chest disorders in adult family members (b) & 25 & 24 & 22 \\
\hline Children with history of asthma & $2 \cdot 7$ & $2 \cdot 8$ & \\
\hline
\end{tabular}

(a) Each mother's estimate of total cigarettes consumed within the house (cf. work).

(b) Chest disorders defined as asthma, bronchitis, or other chest illness음 requiring occasional or regular treatment by general practitioncin.

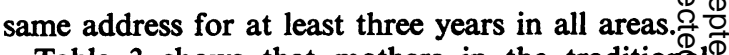

Table 3 shows that mothers in the traditional valley housing reported a greater proportion $\bar{\varnothing} \mathrm{f}_{\bar{\Phi}}$ their children free of colds and sore throats duripgthe previous 12 months than did mothers in the troe council estates; the largest proportion who werd $-\lambda$ stated to have suffered from colds came from the modern council estate with central heating. The frequency of colds and sore throats in affected름 children was also greater in the council estates.

Mothers were also asked about the number of treatments for respiratory illness prescribed by general practitioners for their children during the previous 12 months; the proportion of all younger siblings in families with two or more children whof had received treatment in the previous 12 months was also calculated. Table 4 shows that there were non marked differences between the study areas.

Each mother was asked whether her child had had pneumonia or severe bronchitis in its life and if so, at what age. Only chest infections that had been? treated by a doctor and which had caused illness for at least three days were included. In order tocompare areas, only those children who were living in each area at each age of life were considered; Table 5 shows that there were no marked differences between the areas.

Children who had had their lung function tested were representative of the whole sample of children $\omega$ aged 11 years or less resident in each area; the median periods of residence of their families werce six years (council estate with central heating) 
Table 3 Percentage of children reported free of colds and sore throats in the previous 12 months in each area

\begin{tabular}{|c|c|c|c|c|c|}
\hline & \multirow{2}{*}{$\begin{array}{l}\text { Area A } \\
\text { (298 children) }\end{array}$} & \multirow{2}{*}{$\begin{array}{l}\text { Area } B \\
\text { (252 children) }\end{array}$} & \multirow{2}{*}{$\begin{array}{l}\text { Area } C \\
\text { (213 children) }\end{array}$} & \multicolumn{2}{|c|}{ Significance of differences } \\
\hline & & & & $x^{2}$ & $\boldsymbol{P}$ \\
\hline $\begin{array}{l}\text { Percentage free of colds } \\
\text { Percentage free of sore throats }\end{array}$ & $\begin{array}{l}13 \\
52\end{array}$ & $\begin{array}{l}17 \\
61\end{array}$ & $\begin{array}{l}26 \\
62\end{array}$ & $\begin{array}{r}14 \cdot 37 \\
8 \cdot 43\end{array}$ & $\begin{array}{l}<0.005 \\
<0.025\end{array}$ \\
\hline
\end{tabular}

Table 4 Percentage of children treated by general practitioners in each area for 'chesty coughs' during previous 12 months

\begin{tabular}{|c|c|c|c|}
\hline 'Chesty cough' during previous 12 months & $\begin{array}{l}\text { Area A } \\
\text { (298 children) }\end{array}$ & $\begin{array}{l}\text { Area B } \\
\text { ( } 252 \text { children) }\end{array}$ & $\begin{array}{l}\text { Area } C \\
\text { (213 children) }\end{array}$ \\
\hline $\begin{array}{l}\text { All children under } 11 \text { years } \\
\text { Not needed treatment }(\%) \\
\text { Treated } 1 \text { to } 4 \text { times }(\%) \\
\text { Treated } 5 \text { times or more }(\%)\end{array}$ & $\begin{array}{r}66 \\
28 \\
6\end{array}$ & $\begin{array}{r}66 \\
26 \\
8\end{array}$ & $\begin{array}{r}69 \\
24 \\
7\end{array}$ \\
\hline $\begin{array}{l}\text { Younger siblings in families with two children or more } \\
\text { aged } 11 \text { years or less } \\
\text { Not needed treatment (\%) } \\
\text { Treated } 1 \text { to } 4 \text { times }(\%) \\
\text { Treated } 5 \text { times or more (\%) }\end{array}$ & $\begin{array}{l}147 \text { siblings } \\
62 \\
32 \\
6\end{array}$ & $\begin{array}{l}126 \text { siblings } \\
59 \\
32 \\
9\end{array}$ & $\begin{array}{l}77 \text { siblings } \\
69 \\
23 \\
8\end{array}$ \\
\hline
\end{tabular}

Table 5 Percentage and number of children with history of pneumonia or bronchitis per 100 child-years' exposure to risk

\begin{tabular}{|c|c|c|c|c|c|c|}
\hline \multirow{2}{*}{ Year of life } & \multicolumn{2}{|c|}{ Area $A$} & \multicolumn{2}{|c|}{ Area $B$} & \multicolumn{2}{|c|}{ Area $C$} \\
\hline & $\%$ & No. & $\%$ & No. & $\%$ & No. \\
\hline $\begin{array}{l}0- \\
1- \\
2- \\
3-\end{array}$ & $\begin{array}{r}17 \cdot 2 \\
7 \cdot 3 \\
0 \cdot 6 \\
1 \cdot 7\end{array}$ & $\begin{array}{l}(22) \\
(11) \\
(1) \\
(3)\end{array}$ & $\begin{array}{l}7 \cdot 9 \\
9 \cdot 3 \\
0 \cdot 6 \\
1 \cdot 1\end{array}$ & $\begin{array}{l}(13) \\
(15) \\
(1) \\
(2)\end{array}$ & $\begin{array}{r}12 \cdot 0 \\
5 \cdot 4 \\
1 \cdot 3 \\
1 \cdot 3\end{array}$ & $\begin{array}{l}(20) \\
(9) \\
(2) \\
(2)\end{array}$ \\
\hline
\end{tabular}

The analysis was not continued beyond the fourth year of life as the number of reported infections declines rapidly with age.

seven years (older council estate), and nine or more years (traditional valley housing).

Regression equations which describe the relationship between lung function indices and the height and sex of children are summarised by Polgar and Promadhat (1971). On the basis of the current data, pooled by area, it was found that a proportional model fitted the data more adequately than a linear model for each sex. To compare differences in lung function between areas, a lung function measure standardised for height was derived from this model for each lung function index and for each sex. Because these height standardised measures are different for each sex, the results for girls cannot be directly compared with those for boys (Table 6). The results however show a clear trend; in general, lung function, in terms of the ability to expel air from the lungs (FMF, $\mathrm{FEV}_{\mathbf{0}}$.75) is best in children from the area of traditional housing, Area $C$, and worst in children from the council estate with central heating, Area A. Differences in the average capacity of the lungs (FVC) in each area, however, are slight.

Figures 1 and 2 show the FVC and the FMF for
Table 6 Values of derived lung function measures in girls and boys by area

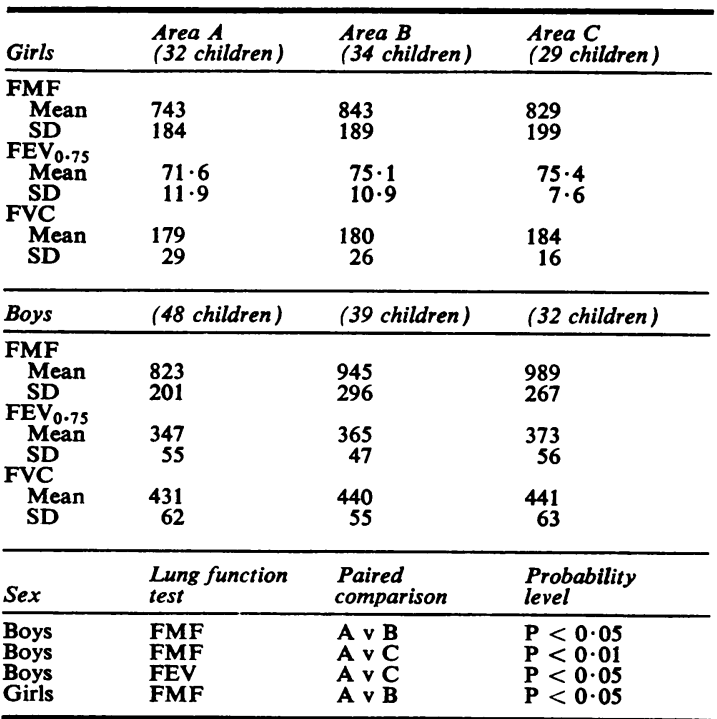

each height group of boys and girls in each housing area. These results demonstrate the extent of the differences shown in Table 6 in terms of the usual measure of lung function. FVC shows little difference between the areas but there are marked differences between the FMF. The differences in $F_{E V} V_{0.75}$ between the areas were similar in pattern to those for FMF.

\section{Discussion}

The findings of this study are that the lung function of children was best in those resident in old housing, 

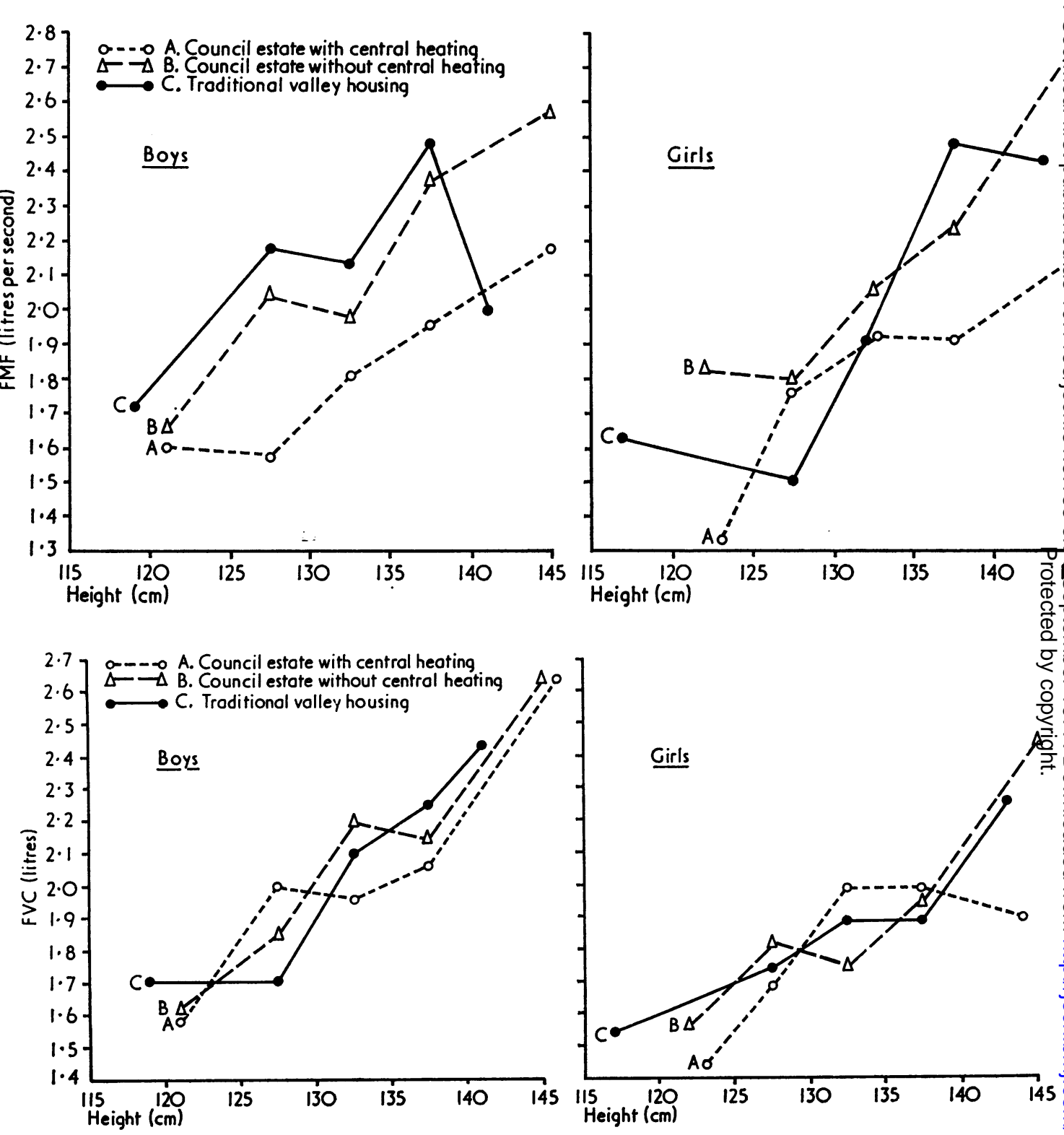

Figs 1 and 2 Mean FMF and FVC in the three housing groups for boys and girls according to height.

intermediate in those in the older council estate, and worst in children resident in the modern council estate with district central heating. This is the converse of that predicted by the original hypothesis.

Both environmental and personal factors are known to affect lung function in children (Holland et al., 1969); these include air pollution, social class, family size, and history of respiratory disease. Respiratory disease in infancy is known to becr affected by parental smoking habit (Colley et al., N 1974); the presence of respiratory disease in siblings of school age may also be pertinent (Leeder et al. 1976).

In a large study in Sheffield, Lunn et al. (1967) found that the lung function of children in onlys? 
the most heavily polluted areas of the city was reduced; air pollution measurements available for the present study area (Department of Trade and Industry, 1972) suggest that pollution levels have been considerably below those of the main industrial cities for some years. In any case significant air pollution is unlikely in the elevated sites of the modern council estates and it is more likely to occur in the valley housing. Social class characteristics and family size are generally similar in the two council estates (Table 2); but some social class differences clearly exist between the inhabitants of the council estates and those of the traditional valley housing. Others (Hollingsworth and Reynolds, 1975) have noted and discussed such differences in the same valley region. The proportion of children with a history of respiratory disease was similar in each area. Although the validity of historical data has been questioned (Hamman et al., 1975), in the current study data were obtained by personal interview with each mother at a home visit. Maternal and total household smoking habits were comparable on the two council estates but fewer mothers were smokers and fewer smoked 20 cigarettes a day in the traditional housing areas. The proportion of families with two or more children aged 11 years or less in which one or more siblings were of early school age, was not substantially different on the two estates (Table 2). The environmental and personal factors already known to contribute to the development of respiratory disease were present to a similar extent on both council estates; these factors were present to a lesser extent among the inhabitants of the traditional valley housing.

One explanation of the findings may be sought in the selective factors which in the first place cause people to be housed on council estates. Many tenants on both council estates had been supported in their applications by medical certificates citing chest disorders, which were usually in adults. This group constituted $10 \%$ of all removals to each estate but over $70 \%$ of removals had not been supported by medical certificates. Forty-five per cent of all families first occupying the older council estate were rehoused from slum clearance areas; only $7 \%$ of families resident on the council estate with central heating were similarly rehoused.

Selective factors seem unlikely therefore to account for the difference in lung function between children resident on the two council estates. Thus some aspect of the domestic environment may account for the findings or the school environments may differ. Both estates are served, however, by modern or modernised schools each with classes of a comparable size.

Mothers from the centrally heated council estate reported an excess occurrence of upper respiratory tract infections among their children which may account for the impairment of these children's lung function relative to those of children from the other areas of bousing. If the domestic environment is responsible for these infections it may act through this mechanism to affect the lung functions.

In terms of conventional lung function indices the mean impairment observed is not trivial. Lung function indices $\left(\mathrm{FEV}_{0.75}\right.$ and $\mathrm{FVC}$ ) in children from the traditional housing are comparable with those in children of the same height resident in Sheffield in 1965 (Lunn, 1965). The average reduction in values of the FMF in children from the centrally heated council estate is $12 \%$, for $\mathrm{FEV}_{0.75}$ it is $7 \%$, and for the FVC the reduction is less than $3 \%$.

Further analysis is in progress to assess the effect of early childhood bronchitis or pneumonia and maternal smoking on subsequent lung function in children. In order to test adequately the hypothesis that the domestic environment accounts for the difference in lung function between children resident on the two council estates a follow-up study is necessary to examine the lung function of larger numbers of children exposed to the domestic environments of both estates since birth.

Particular thanks are due to Dr Mike Robinson of the Department of Child Health, Llandough Hospital, Penarth, Mrs Margery McDermott of the MRC Pneumoconiosis Unit, Penarth, and to $\mathrm{Mr}$ F. Moore and Mrs K. Mahoney.

Reprints from J. W. G. Yarnell, MRC Epidemiology Unit (South Wales), 4 Richmond Road, Cardiff CF2 3AS.

\section{References}

Bland, J. M., Holland, W. W., and Elliott, A. (1974). The development of respiratory symptoms in a cohort of Kent schoolchildren. Bulletin de physio-pathologie respiratoire (Nancy), 10, 699-715.

Cole, T. J. (1975). Linear and proportional regression models in the prediction of ventilatory function. Journal of the Royal Statistical Society, Series A, 138, 297-337.

Colley, J. R. T., Douglas, J. W. B., and Reid, D. D. (1973). Respiratory disease in young adults: Influence of early childhood lower respiratory tract illness, social class, air pollution, and smoking. British Medical Journal, 3, 195-198.

Colley, J. R. T., Holland, W. W., and Corkhill, R. (1974). Influence of passive smoking and parental phlegm on pneumonia and bronchitis in early childhood. Lancet, 2, 1031-1034.

Colley, J. R. T., and Reid, D. D. (1970). Urban and social origins of childhood bronchitis in England and Wales. British Medical Journal, 2, 213-217. 
Cotes, J. E. (1975). Lung Function: Assessment and Application in Medicine, third edition. Blackwell: Oxford.

Department of Trade and Industry (1972). National Survey of Air Pollution (1961-1971). Warren Springs Laboratory: Stevenage.

Hamman, R. F., Halil, T., and Holland, W. W. (1975). Asthma in schoolchildren. Demographic associations and peak expiratory flow rates compared in children with bronchitis. British Journal of Preventive and Social Medicine, 29, 228-238.

Holland, W. W., Halil, T., Bennett, A. E., and Elliott, A. (1969). Factors influencing the onset of chronic respiratory disease. British Medical Journal, 2, 205-208.

Hollingsworth, M. J., and Reynolds, D. (1975). Does council housing cause social deprivation? Paper presented to PTRC Group Meeting (Summer 1975). University of Warwick.

Leeder, S. R., Corkhill, R., Irwig, L. M., Holland, W. W., and Colley, J. R. T. (1976). Influence of family factors on the incidence of lower respiratory illness during the first year of life. British Journal of Preventive and Social Medicine, 30, 203-212.

Lunn, J. E. (1965). Respiratory measurements of 3556 Sheffield schoolchildren. British Journal of Preventive and Social Medicine, 19, 115-122.

Lunn, J. E., Knowelden, J., and Handyside, A. J. (1967). Patterns of respiratory illness in Sheffield infant schoolchildren. British Journal of Preventive and Social Medicine, 21, 7-16.

Polgar, G., and Promadhat, V. (1971). Pulmonary Function Testing in Children. Saunders: Philadelphia.

\section{Statistical Appendix}

Cole (1975) has shown that for adults the relationship

$$
\mathrm{FEV}=\text { height }^{\mathrm{K}}(\mathrm{c}+\mathrm{d} \times \text { age }), \ldots \ldots
$$

where $K$ takes a value near 2 , gives a good fit to lung function data and is convenient to handle. One convenient outcome of this relationship is that if comparison is to be made between groups of individuals of roughly the same age then the simple index FEV/height ${ }^{2}$ may be calculated for each individual and used as the basis of the comparison.

In children height and age are highly correlated and it is usually sufficient to make allowance for height alone. Thus Cole's relationship between FEV, height and age, generalised for all lung function tests (LFT), simplifies to:

$$
\text { LFT }=\text { a. Height }{ }^{\mathrm{K}} \text {, where } \mathrm{a} \text { is a constant }
$$

In our study we found that the relationship

$$
\log (\text { LFT) }=b+K \cdot \log \text { (height) . . . . (3) }
$$

fitted the data for each LFT, in both sexes separately, and in each area separately, consistently better than the simple model

$$
\text { LFT }=c+\text { d. Height . . . . . . . . (4) }
$$

but the difference between the fit of the two models was, in practical terms, small.

For each sex separately, and for data from all three areas pooled we estimated the exponent $\mathrm{K}$ \% from regression (3) above.

$$
\mathbf{L F T}=\mathrm{f} . \mathrm{Height}^{\mathrm{K}} \ldots \ldots \ldots \ldots \ldots \text { (5) }
$$

where $K$ is now fixed, was found to fit the total data, for either sex, and the data within each area marginally better, in each case, than the simple ? linear model (4). That is a one parameter model, $\stackrel{\omega}{\omega}$ with $\mathrm{K}$ fixed, was found to fit better than the two parameter linear model and almost as well as the two parameter transformed model. This was equivalent to forcing all regressions in the trans $\frac{7}{3}$ formed model (3) into parallel lines; these facts $\vec{s}$ together with examination of the fitted lines $i \mathbb{R}^{\mathbb{D}}$ model (3) demonstrate that this approach has nof resulted in the loss of much information while the 3 analysis, interpretation, and understanding of our data are made easier.

To compare FMF, for example, between groups we used the index FMF/height 2.05 for males. Th mean and variance of the index in each group was calculated and direct comparison of the means made. This, in effect, is a comparison of the constant $f$ in equation (5) above. The estimator for $f$ is in this case not least squares but is unbiased.

Our estimated values for the exponent $K$ are $\overrightarrow{\vec{O}}$ displayed in Table A1. These values are considerably 3 lower than estimates quoted by Polgar and Promadhat (1971) who quote values of $\mathrm{K}$ between 2.6 and 2.8 depending on the test and the sex of the child; that our results are lower than theirs may be attribu- $\frac{\rho}{\partial}$

\begin{tabular}{|c|c|c|}
\hline Lung function test & Males & Females \\
\hline $\begin{array}{l}\text { FMF } \\
\text { FEV } 0.75 \\
\text { FVC }\end{array}$ & $\begin{array}{l}2 \cdot 05 \\
2 \cdot 20 \\
2 \cdot 20\end{array}$ & $\begin{array}{l}2 \cdot 54 \\
2 \cdot 04 \\
1 \cdot 89\end{array}$ \\
\hline
\end{tabular}
table to the differences in the age range of our children who were younger and smaller than those studied by Polgar and Promadhat.

Table A1 Value for exponent K estimated from pooled data 